\title{
Cost-effectiveness analysis of oral anti-viral drugs used for treatment of chronic hepatitis B in Turkey
}

\author{
Guvenc Kockaya ${ }^{1}$, Akin Kose ${ }^{1}$, Fatma Betul Yenilmez ${ }^{2 *}$, Oktay Ozdemir ${ }^{3}$ and Ece Kucuksayrac ${ }^{1}$
}

\begin{abstract}
Background: All international guidelines suggested that Tenofovir and Entecavir are the primary drugs at the first line therapy for the treatment of chronic hepatitis B (CHB). However, in Turkey these medications reimbursed at the second line therapy according to the Healthcare Implementation Notification. The aim of this study is to compare the cost effectiveness of oral antiviral treatment strategies in CHB for Turkey using lamuvidine, telbuvidine, entecavir, and tenofovir as medications.
\end{abstract}

Methods: The analysis was conducted using Markov models. The analysis scenarios based on first line treatment options with Lamuvidine, Telbuvidine, Entecavir, and Tenofovir as the medications. In the analysis, inadequate response or resistance after receiving 12 months of the treatment with Entecavir and Telbivudine were compared to the results found from switching from Entecavir to Tenofovir or from switching from Telbuvidine to Tenofovir. In additional, inadequate response or resistance after receiving 6 months of the treatment for Lamivudine was compared to the results found from switching from Lamivudine to Tenofovir. The study population included men and women, who were 40 years of age. The patients ' compliance was estimated $100 \%$ for all of the therapy options. The model duration was constructed to evaluate, treatment strategy duration of 40 years. The cost of medications, examinations/ follow-ups and complications were included in the model. Years of Potential Life Lost was used as the health outcome. An incremental cost-effectiveness ratio analysis has been conducted.

Results and discussion: While the minimum years of life lost was found as 0.22 with tenofovir treatment in 5 years, treatment cost was calculated as $12,169 \mathrm{TL}$. These values were detected as 0.56 years and $7727 \mathrm{TL}, 0.37$ years and $12,770 \mathrm{TL}$, respectively for lamuvidine and telbuvidine treatments. The maximum years of life lost and treatment cost was with lamuvidine treatment were detected as 1.60 years and $18,813 \mathrm{TL}$ and, secondly 0.89 years and 24,007 TL for lamuvidine-tenofovir treatment during 10 years. The minimum years of life lost and cost are 0.54 year and 35,821 TL for tenofovir treatment during 10 years. The minimum years of life lost and cost were determined as 1.21 years and $52,839 \mathrm{TL}$ for tenofovir treatment strategy during 20 years. During 30 years period, tenofovir treatment was found to have the minimum years of life lost (1.73 years) and minimum cost $(84,149 \mathrm{TL})$. When the results of 40 years period were analyzed, years of life lost and costs are 2.06 years and 119,604 TL, 2.13 years and 162,115 TL, 2.13 years and $161,642 \mathrm{TL}, 6.52$ years and 147,245 TL, 3.20 years and 132,157 TL, 4.10 years and 151,059 TL and 3.05 years and 138,182 TL for tenofovir, entecavir, entecavir-tenofovir, lamuvidine, lamuvidine-tenofovir, telbivudine and telbivudine-tenofovir.

Conclusions: In the model presented in this study, in cost effectiveness analysis about CHB treatments, Tenofovir was found to be one of the cost effective methods in comparison with other treatment strategies different time intervals. Beyond this achievement Tenofovir has shown to reduce cumulative treatment cost in first line CHB treatment when compared with regard to 40 year cumulative treatment cost.

\footnotetext{
*Correspondence: fatmabetulyenilmez@hotmail.com

${ }^{2}$ Akıl Consultancy, Ankara, Turkey

Full list of author information is available at the end of the article
} provided you give appropriate credit to the original author(s) and the source, provide a link to the Creative Commons license, and indicate if changes were made. The Creative Commons Public Domain Dedication waiver (http://creativecommons.org/ publicdomain/zero/1.0/) applies to the data made available in this article, unless otherwise stated. 
Keywords: Chronic hepatitis B, Cost effectiveness, Oral antiviral treatment

\section{Background}

Hepatitis B is among the most common infectious diseases worldwide. At least 2 billion individuals are estimated to have been infected with the Hepatitis B virus (HBV), and 378 million individuals (6\% of the world's population) are estimated to be chronic carriers worldwide. Cirrhosis, hepatic failure, or hepatocellular cancer are known to develop in approximately $40 \%$ of all chronic hepatitis B (CHB) cases [1, 2].

The prevalence of the hepatitis $B$ surface antigen (HBsAg) was determined as $4.57 \%$ according to a metaanalysis conducted to investigate $\mathrm{HBV}$ epidemiology in Turkey. The confidence interval (CI) was determined as 3.58-5.76, and the estimated number of $\mathrm{CHB}$ cases was 3.3 million. This ratio increases to $9.8 \%$ in the eastern part of Turkey. According to the epidemiologic data obtained between 1999 and 2009, while Hepatitis B prevalence is $3.23 \%$ in the age group of $0-14$ years, it is $5.77 \%$ in the age group of $15-24$ years. This ratio is $7.08 \%$ in the $25-34$ age group, $6.93 \%$ in the $35-44$ age group, $6.13 \%$ in the $45-54$ age group, and $5.02 \%$ in the $55-64$ age group. Hepatitis B surface antigen (HBsAg) prevalence increases with age according to this study [3].

Oral antiviral treatment is the most convenient way to control and stabilize the CHB disease. The indications are generally the same for HBeAg positive and negative patients [4]. Treatment is usually based on assessing the combination of three criteria: serum HBV DNA values, ALT values, and the stage of the hepatic disease [4].

The goal of treatment for Chronic Hepatitis B is to prevent the progression to cirrhosis, reducing the need for liver transplantation and improving the quality of life of the patient. Both national and international CHB treatment guidelines reveal that HBV DNA should be strongly suppressed for achieving these goals. With the treatment, the histopathological findings of the liver and the biochemical parameters are improved and the long-term complications of $\mathrm{CBH}$ are reduced as well [4].

Some current treatment guidelines, such as the European Association for the Study of the Liver (EASL), the American Association for the Study of Liver Diseases (AASLD) and the Asia Pacific Association for the Study of the Liver (APASL) recommend potent Oral Anti-viral (OAV) treatments as the first choice in initial therapy for achieving the specified goals [4-6]. In Turkey, changes have been made in Healthcare Reimbursement Rules to be aligned with International Hepatology Management and Treatment guidelines. Potent OAV treatments, such as Tenofovir and Entecavir, were approved to be used for a low viral loaded patient population in 2014 [8].
Tenofovir maintains the effective suppression of HBV DNA through 8 years of treatment with no evidence of TDF resistance in contrast to other agents [8]. In addition to the effective suppression of HBV DNA with a TDF treatment, there have been histological improvements in a 5-year treatment both in cirrhotic and noncirrhotic $\mathrm{CHB}$ patients [9]. As Entecavir has a $1.2 \%$ resistance potential in a naïve treatment group, Entecavir patients should also be closely monitored for resistance. In addition, in long-term use, the cumulative probability of Entecavir resistance development in lamivudinerefractory patients was reported to be as high as $57 \%$ over 6 years of treatment [11]. In a 2-year Globe trial, it was shown that the Telbivudine resistance rates were $25.1 \%$ for $\mathrm{HBeAg}$ positive patients and $10.8 \%$ for $\mathrm{HBeAg}$ negative patients. The M204I signature mutation was the primary basis for Telbivudine resistance, with secondary mutations detected at the L80, L180, and other codons. In vitro studies have shown that HBV with the M204I mutation remains sensitive to the nucleotide analogues adefovir, dipivoxil, and tenofovir [7].

Lamivudine has been approved in Turkey since 2000. For a long period of time, lamivudine was the only treatment before Entecavir approval in 2006. Tenofovir and Telbivudine were approved in Turkey in 2007 and 2008, respectively. Based on the Globe [7] study's results, a road map concept has been generated by the Social Security Institute [10]. From 2009 to 2015, Lamivudine and Telbivudine was stratified as the first line treatment options for low viral loaded patients (HBV DNA $<104 \mathrm{IU} / \mathrm{mL}$ ). As a result, $2 / 3$ of HBV patients had been treated with Lamivudine and Telbivudine. Tenofovir was only prescribed for high viral loaded patients (HBV DNA $>104 \mathrm{IU} / \mathrm{mL}$ ) or patients with a detectable HBV DNA level after 6 months of therapy with Lamivudine or Telbivudine.

This analysis compares Lamivudine, Telbivudine, Entecavir, and Tenofovir, the oral antiviral agents used for first line CHB treatment according to the Health Application Notification, which defined the reimbursement process in Turkey.

\section{Methods}

\section{Treatment strategies}

The Markov model was used in the present analysis. The Markov model is designed to include the entire disease whether the patients respond to therapy or not, complications develop in the case of irresponsiveness to therapy, complications progress in years, and a follow up for the patients until death (Fig. 1). In the analysis scenarios, Lamivudine (3TC), Telbivudine (LdT), Entecavir 
(ETV), and Tenofovir (TDF) use was planned for first line therapy. Treatments that switched to Tenofovir from Entecavir (ETV- TDF) and to Tenofovir from Telbivudine (LdT-TDF) in the case of an inadequate response or resistance development after 12 months or that switched to Tenofovir from Lamivudine (3TC-TDF) in the case of an inadequate response or responsiveness 6 months later were included in the analysis. A single strategy was also included during the model time in all molecules in transitional treatments. The resistance rates of the drugs and the estimated 5-year virologic response rates for each treatment were obtained from published studies.

\section{Treatment population}

The age for beginning treatment was 40 years, and the duration of treatment was 40 years, which is consistent with the life expectancy. Of the patients, $50 \%$ were assumed to be male and $50 \%$ were assumed to be female in the Turkish population [8]. They were assumed to be $100 \%$ compliant to therapy. The HBeAg positivity rate was assumed to be $30 \%$ [9]. The transition probability between disease stages was taken from the analysis of Kanwal et al. [13]. (Table 1). Tables 2 and 3 show the response rates of $\mathrm{CHB}$ treatments in the model and the resistance rates. The rates of resistance developing during the therapy and the cumulative resistance rates for the first 3 years of therapy were obtained from the data of the paper published by Marcellin et al., and the assumptions were used for the resistance rates after 3 years [11, 12]. The resistance data of Entecavir treatment for the first 6 years were obtained from the study published by Tenney et al., and the assumptions were made for the following years [14]. The Lamivudine resistance data were calculated proportionally with the yearly resistance rates of the patients who had a high viral load for the fourth and the fifth years, and it was assumed to be half of the previous year for each year after the fifth year [15]. The Telbuvidin response data were obtained from the data of Zeuzem et al. and calculated proportionally with 3TC treatment at the third year and thereafter [16] (Table. 2, 3).

The rates of response developing during therapy and the data were obtained from the paper published by Marcellin et al., and the assumptions were used for the response rates for 48 weeks of therapy for Tenofovir [17]. The response data of Entecavir treatment for 48 weeks

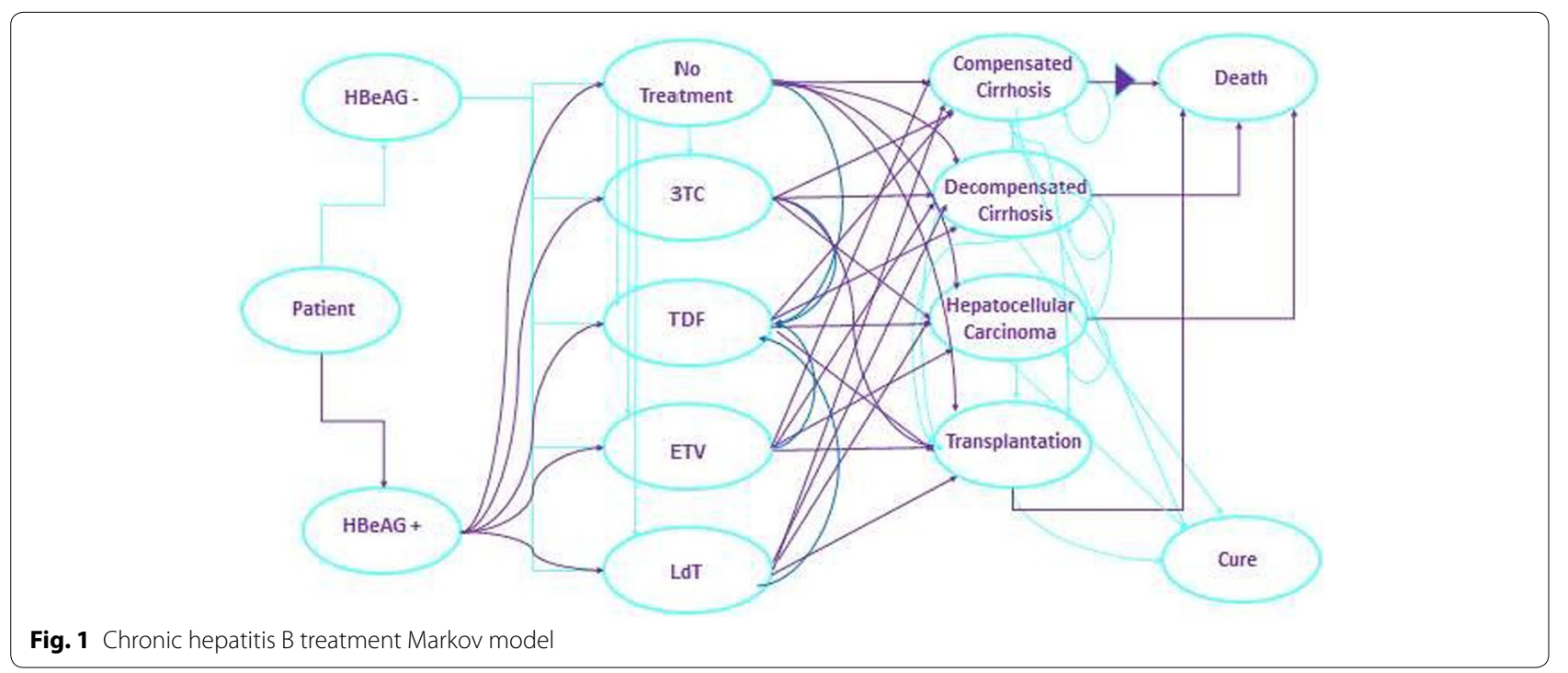

Table 1 Transition rates between chronic hepatitis B and diseases [13]

\begin{tabular}{llllr}
\hline & Decompensated cirrhosis & Hepatocellular cancer & Transplantation & Death (\%) \\
\hline Compensated cirrhosis & $7.3 \%$ & $3.4 \%$ & $0.0 \%$ & 4.9 \\
Decompensated cirrhosis & - & $3.4 \%$ & $20.0 \%$ & 19.0 \\
Hepatocellular cancer & - & - & $25.0 \%$ & 43.3 \\
transplantation & - & - & - & 6.9 \\
\hline
\end{tabular}


Table 2 Response rates to chronic hepatitis B treatments [17-20]

\begin{tabular}{|c|c|c|c|c|c|c|c|c|c|c|}
\hline 24th week & TDF & ETV & 3TC & LAM & LdT & TDF & ETV & $3 T C$ & LAM & LdT \\
\hline$<300$ & 84.8 & 84.8 & 73.0 & 71.0 & 80.0 & 48.9 & 37.0 & 34.0 & 32.0 & 45.0 \\
\hline $300-104$ & 9.7 & 9.7 & 15.0 & 20.0 & 15.0 & 32.5 & 40.0 & 26.0 & 31.0 & 31.0 \\
\hline $104-105$ & 2.7 & 2.7 & 3.6 & 2.7 & 1.5 & 8.9 & 11.0 & 12.0 & 11.1 & 7.2 \\
\hline $105-106$ & 0.2 & 0.2 & 1.5 & 1.1 & 0.6 & 0.8 & 1.0 & 5.0 & 4.6 & 3.0 \\
\hline$>106$ & 2.7 & 2.7 & 6.9 & 5.2 & 2.9 & 8.9 & 11.0 & 23.0 & 21.3 & 13.8 \\
\hline \multicolumn{11}{|l|}{ 48th week } \\
\hline$<300$ & 93.2 & 93.3 & 75.6 & 71.4 & 88.3 & 76.1 & 69.1 & 39.8 & 40.4 & 60.0 \\
\hline $300-104$ & 4.2 & 4.1 & 12.5 & 18.4 & 8.0 & 19.1 & 24.7 & 18.2 & 28.1 & 21.5 \\
\hline $104-105$ & 1.6 & 1.6 & 5.1 & 7.5 & 3.3 & 3.4 & 4.4 & 11.7 & 18.1 & 13.8 \\
\hline $105-106$ & 0.3 & 0.3 & 2.0 & 0.8 & 0.1 & 0.5 & 0.6 & 9.3 & 4.1 & 1.4 \\
\hline$>106$ & 0.6 & 0.6 & 4.8 & 1.9 & 0.3 & 0.9 & 1.2 & 21.0 & 9.3 & 3.3 \\
\hline
\end{tabular}

Values are expressed as \%

Table 3 Resistance to therapy for chronic Hepatitis B treatment [11-16]

\begin{tabular}{|c|c|c|c|c|c|c|c|c|c|c|c|c|c|c|c|c|c|c|c|}
\hline Years & 1 & 2 & 3 & 4 & 5 & 6 & 7 & 8 & 9 & 10 & 11 & 12 & 13 & 14 & 15 & 16 & 17 & 18 & 19 \\
\hline \multicolumn{20}{|l|}{ Resistance } \\
\hline TDF & 0.0 & 0.0 & 0.0 & 0.0 & 0.0 & 0.0 & 0.0 & 0.0 & 0.0 & 0.0 & 0.0 & 0.0 & 0.0 & 0.0 & 0.0 & 0.0 & 0.0 & 0.0 & 0.0 \\
\hline ETV & 0.2 & 0.3 & 0.7 & 0.0 & 0.0 & 0.0 & 0.0 & 0.0 & 0.0 & 0.0 & 0.0 & 0.0 & 0.0 & 0.0 & 0.0 & 0.0 & 0.0 & 0.0 & 0.0 \\
\hline $3 \mathrm{TC}$ & 6.7 & 11.3 & 21.0 & 11.3 & 6.4 & 3.2 & 1.6 & 0.8 & 0.4 & 0.2 & 0.1 & 0.0 & 0.0 & 0.0 & 0.0 & 0.0 & 0.0 & 0.0 & 0.0 \\
\hline LtD/Hbe- & 1.1 & 2.2 & 4.1 & 2.2 & 1.2 & 0.6 & 0.3 & 0.2 & 0.1 & 0.0 & 0.0 & 0.0 & 0.0 & 0.0 & 0.0 & 0.0 & 0.0 & 0.0 & 0.0 \\
\hline LtD/Hbe+ & 5.0 & 6.3 & 11.6 & 6.3 & 3.5 & 1.8 & 0.9 & 0.4 & 0.2 & 0.1 & 0.1 & 0.0 & 0.0 & 0.0 & 0.0 & 0.0 & 0.0 & 0.0 & 0.0 \\
\hline \multicolumn{20}{|c|}{ Cumulative resistance } \\
\hline TDF & 0.0 & 0.0 & 0.0 & 0.0 & 0.0 & 0.0 & 0.0 & 0.0 & 0.0 & 0.0 & 0.0 & 0.0 & 0.0 & 0.0 & 0.0 & 0.0 & 0.0 & 0.0 & 0.0 \\
\hline ETV & 0.2 & 0.5 & 1.2 & 1.2 & 1.2 & 1.2 & 1.2 & 1.2 & 1.2 & 1.2 & 1.2 & 1.2 & 1.2 & 1.2 & 1.2 & 1.2 & 1.2 & 1.2 & 1.2 \\
\hline 3TC & 6.7 & 18.0 & 39.0 & 50.3 & 56.7 & 59.9 & 61.5 & 62.3 & 62.7 & 62.9 & 63.0 & 63.1 & 63.1 & 63.1 & 63.1 & 63.1 & 63.1 & 63.1 & 63.1 \\
\hline LtD/Hbe- & 1.1 & 3.3 & 7.4 & 9.6 & 10.8 & 11.4 & 11.8 & 11.9 & 12.0 & 12.0 & 12.1 & 12.1 & 12.1 & 12.1 & 12.1 & 12.1 & 12.1 & 12.1 & 12.1 \\
\hline LtD/Hbe + & 5.0 & 11.3 & 22.9 & 29.1 & 32.7 & 34.4 & 35.3 & 35.8 & 36.0 & 36.1 & 36.1 & 36.2 & 36.2 & 36.2 & 36.2 & 36.2 & 36.2 & 36.2 & 36.2 \\
\hline
\end{tabular}

Values are expressed as \%

were obtained from the study published by Arnold et al. [18]. The Lamivudine response data were obtained from the publications of Yuan et al. and Lai et al. $[19,20]$. The Telbuvidin resistance data were obtained from the data of Lai et al. All assumptions and selected articles for modeling were based on three experts' opinions.

\section{Cost calculation}

The cumulative treatment cost was calculated by including the costs of medicines, tests/follow ups, and complications. The costs paid by the Social Security Institution (SSI) on September 1, 2014 were taken for the calculation of the costs of medicines and tests/follow ups. The average annual costs of the treatment strategies included in the model according to the costs paid by the published figures are shown in Table 4 . An annual $3 \%$ discount rate was used for the calculation of the costs over the 40 -year model process [21]. It was assumed that the discount rate covered the inflator and deflator effect.

The complication costs were taken from the study published in 2009 [22, 23]. The data of 2014 were obtained by adapting the 2009 costs to a $3 \%$ discount rate [21] (Table 5). The transition risks according to the plasma HBV DNA levels and the inter-transition of the complications and the mortality rates were taken from the published studies in the application of the complication costs to the treatment strategies [11-17, 19, 24-26].

\section{Calculation of clinical effectiveness}

Years of life lost (YLL) was used for the clinical effectiveness parameter. The life expectancy of healthy individuals according to the life expectancy at birth in Turkey was used for the response to therapy, and it was calculated again for each year in the model [27]. In the case 
Table 4 Treatment strategies for chronic hepatitis B in Turkey and the annual treatment costs

\begin{tabular}{lllllr}
\hline Medicines & Dose & Unit & Dose (mg/tablet) & $\begin{array}{c}\text { Package (tablet/box) } \\
\text { The average annual public } \\
\text { Cost of treatment (TL) }\end{array}$ \\
\hline $3 T C$ & 100 & mg/day & 100 & 28 & 30 \\
ETV & 0.5 & $\mathrm{mg} / \mathrm{kg} /$ day & 0.5 & 30 & 3497.53 \\
TDF & 300 & $\mathrm{mg} /$ day & 300 & 28 & 236.42 \\
LdT & 600 & mg/day & 600 & 2033.61 \\
\hline
\end{tabular}

Table 5 The average annual costs of disease conditions in Turkey

\begin{tabular}{llc}
\hline Disease states & \multicolumn{2}{l}{ Original costs (TL/year) } \\
\cline { 2 - 3 } Year & $\mathbf{2 0 0 9 ( T L )}$ & $\mathbf{2 0 1 4}^{\mathbf{a}}$ (TL) \\
\hline Compensated cirrhosis & 6778 & 7857 \\
Decompensated cirrhosis & 7573 & 8780 \\
Hepatocellular carcinoma & 31,044 & 35,989 \\
\hline
\end{tabular}

2014 costs were calculated by using $3 \%$ reduction ratio according to 2009

of irresponsiveness to therapy, published complications and mortality transitions were used for the calculation of the YLL, and it was calculated again for each year in the model [11, 12, 14, 16, 19, 22-26].

\section{Comparison of overall cost and clinical effectiveness}

The calculated cumulative treatment cost and clinical effectiveness outcomes were compared according to 5 , $10,20,30$, and 40 years of data calculated in the model.

\section{Comparison of cost-effectiveness}

The incremental cost-effectiveness ratio (ICER) was used for the comparison of cost-effectiveness. The costs were sorted from minimum to maximum for the ICER calculation. An assessment was performed between the second leading minimum cost and the maximum cost. If a treatment cost was lower than the next treatment cost and its effectiveness was higher, it was stated to be "superior," and the assessment was performed with the next treatment. If the effectiveness was high along with a high cost, the ICER formulation was applied as follows [27]:

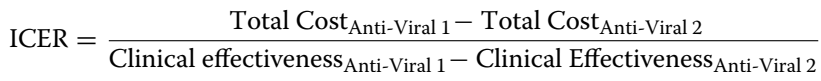

The cumulative treatment cost (medicines, tests/follow ups, and complications) was calculated at the end of 40 years, which is the model year, and the YLL was used for the comparison of cost effectiveness.

\section{Sensitivity analysis}

The sensitivity analysis was conducted to show the impact of the change of the parameters on the cost-effectiveness ratio. A $25 \%$ increase and decrease of the inputs method was used for the analysis [28].

\section{Results and discussion}

The treatment strategies were determined and analyzed for Tenofovir (TDF), Entecavir (ETV), switching to Tenofovir from Entecavir (ETV-TDF), Lamivudine (3TC), switching to Tenofovir from Lamivudine (3TC-TDF), Telbivudine (LdT), and switching to Tenofovir from Telbivudine (LdT-TDF).

\section{Comparison of overall cost and clinical effectiveness}

While the minimum years of life lost was found to be 0.22 with TDF treatment for 5 years, the treatment cost was calculated as 12,169 TL. These values were identified as 0.56 years and $7727 \mathrm{TL}$ and 0.37 years and $12,770 \mathrm{TL}$, respectively, for the $3 \mathrm{TC}$ and $\mathrm{LdT}$ treatments.

The maximum years of life lost and the treatment cost with the 3TC treatment were identified as 1.60 years and $18,813 \mathrm{TL}$, and, secondly, 0.89 years and 24,007 TL for the 3TC-TDF treatment for 10 years. The years of life lost and the treatment costs are 0.78 years and 26,848 $\mathrm{TL}, 1.01$ years and 27,295 TL, 0.57 years and 35,918 TL, 0.57 years and $35,918 \mathrm{TL}$ for the other treatment alternatives LdT-TDF, LdT, ETV, and ETV-TDF, respectively. The minimum years of life lost and cost are 0.54 year and 35,821 TL for the TDF treatment for 10 years (Table 6).

The minimum years of life lost and the cost were determined as 1.21 years and 52,839 TL for the TDF treatment strategy for 20 years. The years of life lost and the cost for the other treatment strategies, ETV, ETV-TDF, LdTTDF, 3TC-TDF, LdT, and 3TC, are 1.25 years and 74,592 $\mathrm{TL}, 1.25$ years and 74,367 TL, 1.77 years and 58,542 TL, 1.91 years and 54,785 TL, 2.37 years and 61,448 TL, and 3.81 years and 49,974 TL, respectively.

Over a 30-year period, the TDF treatment was found to have the minimum years of life lost (1.73 years) and the minimum cost $(84,149 \mathrm{TL})$. The years of life lost and the treatment costs are 1.79 years and 116,425 TL for ETV, 1.79 years and 116,074 TL for ETV-TDF, 5.50 years and 92,666 TL for 3TC, 2.70 years and 90,517 TL for 3TCTDF, 3.44 years and 102,458 TL for LdT, and 2.56 years and 95.357 $\mathrm{T}$ for LdT-TDF (Table 6). 
When the results of the 40-year period were analyzed, the years of life lost and costs are 2.06 years and 119,604 TL, 2.13 years and 162,115 TL, 2.13 years and 161,642 TL, 6.52 years and 147,245 TL, 3.20 years and $132,157 \mathrm{TL}, 4.10$ years and $151,059 \mathrm{TL}$, and 3.05 years and 138,182 TL for TDF, ETV, ETV-TDF, 3TC, 3TC-TDF, LdT, and LdT-TDF, respectively (Table 6).

\section{Comparison of cost-effectiveness}

According to the 40-year treatment model designed for an incremental cost-effectiveness comparison, the TDF treatment dominated the alternative treatment strategies, as it provided the minimum total cost and the minimum years of life lost. In other words, TDF was determined to be the most cost-effective treatment strategy compared to the other treatment strategies (Table 7).

In Table 6, the minimum treatment cost belongs to TDF with $119,604 \mathrm{TL}$ in the total cost and drug cost comparison. The drug cost is $84,885 \mathrm{TL}$ for the TDF treatment. The total treatment cost is $147,244 \mathrm{TL}$, and the drug cost is $28,151 \mathrm{TL}$ for the $3 \mathrm{TC}$ treatment.

\section{Sensitivity analysis}

The sensitivity analysis was conducted for $25 \%$ varying for each parameters. The most effective parameter for cost-effectiveness was observed as a virologic respond.

In all scenarios of the sensitivity analysis, it was shown that TDF has the lowest cost and the highest effectiveness. Based on these results, TDF dominated all options in all scenarios (Tables 8, 9).

\section{Conclusions}

Currently, CHB treatment has achieved positive results regarding a high virologic response and a low resistance [4]. All published current guidelines recommend Tenofovir and Entecavir as the first drug for CHB treatment.

Table 6 Years of life lost and treatment costs for each 10 years per capita

\begin{tabular}{|c|c|c|c|c|c|c|c|c|}
\hline \multirow[t]{2}{*}{ Treatments } & \multicolumn{2}{|c|}{ Year 10} & \multicolumn{2}{|c|}{ Year 20} & \multicolumn{2}{|c|}{ Year 30} & \multicolumn{2}{|c|}{ Year 40} \\
\hline & YLL & Total cost (TL) & YLL & Total cost (TL) & YLL & Total cost (TL) & YLL & Total cost (TL) \\
\hline TDF & 0.54 & 24,948 & 1.21 & 52,839 & 1.73 & 84,149 & 2.06 & 119,604 \\
\hline 3TC-TDF & 0.89 & 24,007 & 1.91 & 54,785 & 2.70 & 90,517 & 3.20 & 132,157 \\
\hline LdT-TDF & 0.78 & 26,848 & 1.77 & 58,542 & 2.56 & 95,357 & 3.05 & 138,182 \\
\hline 3TC & 1.60 & 18,813 & 3.81 & 49,974 & 5.50 & 92,666 & 6.52 & 147,245 \\
\hline LdT & 1.01 & 27,295 & 2.37 & 61,448 & 3.44 & 102,458 & 4.10 & 151,059 \\
\hline ETV-TDF & 0.57 & 35,821 & 1.25 & 74,366 & 1.79 & 116,074 & 2.13 & 161,642 \\
\hline ETV & 0.57 & 35,918 & 1.25 & 74,592 & 1.79 & 116,425 & 2.13 & 162,115 \\
\hline
\end{tabular}

Table 7 Incremental cost effectiveness analysis of chronic hepatitis B treatments

\begin{tabular}{|c|c|c|c|c|c|}
\hline Treatments & Total cost (TL) & YLL & Cost difference (TL) & Year difference & ICER \\
\hline TDF & 119,604 & 2.06 & & & \\
\hline ETV-TDF & 161,642 & 2.13 & 42,037 & 0.07 & Dominated \\
\hline ETV & 162,115 & 2.13 & 42,511 & 0.07 & Dominated \\
\hline LdT-TDF & 138,182 & 3.05 & 18,577 & 0.99 & Dominated \\
\hline 3TC-TDF & 132,157 & 3.20 & 12,552 & 1.14 & Dominated \\
\hline LdT & 151,059 & 4.10 & 31,455 & 2.04 & Dominated \\
\hline $3 \mathrm{TC}$ & 147,245 & 6.52 & 27,640 & 4.56 & Dominated \\
\hline
\end{tabular}

Calculations were done according to the constructed 40-year treatment model

Table $825 \%$ varying impact on TDF outcomes

\begin{tabular}{lllcc}
\hline & Age & $\begin{array}{l}\text { HBeAg (-) } \\
\text { rate (\%) }\end{array}$ & $\begin{array}{l}\text { TDF: virologic response } \\
\text { 48th week in HBeAg (-) (\%) }\end{array}$ & $\begin{array}{l}\text { TDF: virologic response } \\
\text { 48th week in HBeAg (+) (\%) }\end{array}$ \\
\hline Base case & 40 & 70 & 93.2 & $\begin{array}{l}\text { TDF annual } \\
\text { drug cost (TL) }\end{array}$ \\
$25 \%$ increase & 50 & 88 & 100.0 & 95.1 \\
$25 \%$ decrease & 30 & 53 & 69.9 & 57.1 \\
\hline
\end{tabular}


Table 9 Sensitivity analysis results for the impact of each parameter on cost-effectiveness

\begin{tabular}{|c|c|c|c|c|c|c|c|}
\hline Parameter & Change & New value & & $\begin{array}{l}\text { Total } \\
\text { cost (TL) }\end{array}$ & YLL & $\begin{array}{l}\text { Cost } \\
\text { difference (TL) }\end{array}$ & $\begin{array}{l}\text { Year } \\
\text { difference }\end{array}$ \\
\hline \multirow[t]{10}{*}{ Age $=50$ years } & & 50 & TDF & 119,604 & 1.302 & & \\
\hline & & & ETV-TDF & 161,642 & 1.347 & 42,037 & 0.045 \\
\hline & & & ETV & 162,115 & 1.347 & 42,511 & 0.046 \\
\hline & & & LdT-TDF & 138,182 & 1.923 & 18,577 & 0.622 \\
\hline & & & 3TC-TDF & 132,157 & 2.028 & 12,552 & 0.726 \\
\hline & & & LdT & 151,059 & 2.581 & 31,455 & 1.280 \\
\hline & & & $3 T C$ & 147,245 & 4.109 & 27,640 & 2.807 \\
\hline & & & TDF & 119,604 & 2.987 & & \\
\hline & & & ETV-TDF & 161,642 & 3.088 & 42,037 & 0.101 \\
\hline & & & ETV & 162,115 & 3.089 & 42,511 & 0.102 \\
\hline \multirow[t]{7}{*}{ Age $=30$ years } & & 30 & LdT-TDF & 138,182 & 4.429 & 18,577 & 1.442 \\
\hline & & & 3TC-TDF & 132,157 & 4.621 & 12,552 & 1.634 \\
\hline & & & LdT & 151,059 & 5.954 & 31,455 & 2.967 \\
\hline & & & $3 \mathrm{TC}$ & 147,245 & 9.453 & 27,640 & 6.465 \\
\hline & & & TDF & 119,411 & 2.025 & & \\
\hline & & & ETV-TDF & 161,353 & 2.079 & 41,943 & 0.054 \\
\hline & & & ETV & 161,826 & 2.079 & 42,416 & 0.055 \\
\hline \multirow[t]{7}{*}{ HBeAg $(-)$ rate } & $25 \%$ increase & $88 \%$ & LdT-TDF & 132,215 & 2.656 & 12,804 & 0.631 \\
\hline & & & 3TC-TDF & 127,731 & 2.907 & 8320 & 0.882 \\
\hline & & & LdT & 137,643 & 3.152 & 18,233 & 1.128 \\
\hline & & & $3 T C$ & 128,004 & 5.124 & 8593 & 3.099 \\
\hline & & & TDF & 119,798 & 2.096 & & \\
\hline & & & ETV-TDF & 161,930 & 2.183 & 42,132 & 0.087 \\
\hline & & & ETV & 162,404 & 2.183 & 42,606 & 0.088 \\
\hline \multirow{7}{*}{$\mathrm{HBeAg}(-)$ rate } & $25 \%$ decrease & $53 \%$ & LdT-TDF & 144,149 & 3.445 & 24,351 & 1.349 \\
\hline & & & 3TC-TDF & 136,582 & 3.487 & 16,784 & 1.391 \\
\hline & & & LdT & 164,475 & 5.045 & 44,677 & 2.949 \\
\hline & & & $3 \mathrm{TC}$ & 166,486 & 7.907 & 46,688 & 5.811 \\
\hline & & & TDF & 119,573 & 2.055 & & \\
\hline & & & ETV-TDF & 161,642 & 2.131 & 42,068 & 0.076 \\
\hline & & & ETV & 162,115 & 2.131 & 42,542 & 0.076 \\
\hline \multirow{7}{*}{$\begin{array}{l}\text { TDF: virologic response 48th week } \\
\text { in } \mathrm{HBeAg}(-)\end{array}$} & $25 \%$ increase & $100.0 \%$ & LdT-TDF & 138,176 & 3.049 & 18,603 & 0.994 \\
\hline & & & 3TC-TDF & 132,148 & 3.196 & 12,574 & 1.140 \\
\hline & & & LdT & 151,059 & 4.099 & 31,486 & 2.043 \\
\hline & & & $3 \mathrm{TC}$ & 147,245 & 6.515 & 27,672 & 4.460 \\
\hline & & & TDF & 119,711 & 2.078 & & \\
\hline & & & ETV-TDF & 161,642 & 2.131 & 41,931 & 0.053 \\
\hline & & & ETV & 162,115 & 2.131 & 42,404 & 0.053 \\
\hline \multirow{7}{*}{$\begin{array}{l}\text { TDF: Virologic response 48th week } \\
\text { in } \mathrm{HBeAg}(-)\end{array}$} & $25 \%$ decrease & $69.9 \%$ & LdT-TDF & 138,202 & 3.054 & 18,491 & 0.976 \\
\hline & & & 3TC-TDF & 132,186 & 3.202 & 12,475 & 1.124 \\
\hline & & & LdT & 151,059 & 4.099 & 31,348 & 2.021 \\
\hline & & & $3 T C$ & 147,245 & 6.515 & 27,534 & 4.437 \\
\hline & & & TDF & 119,538 & 2.049 & & \\
\hline & & & ETV-TDF & 161,642 & 2.131 & 42,103 & 0.082 \\
\hline & & & ETV & 162,115 & 2.131 & 42,577 & 0.082 \\
\hline $\begin{array}{l}\text { TDF: Virologic response 48th week } \\
\text { in } \mathrm{HBeAg}(+)\end{array}$ & $25 \%$ increase & $95.2 \%$ & LdT-TDF & 138,153 & 3.044 & 18,614 & 0.996 \\
\hline
\end{tabular}


Table 9 continued

\begin{tabular}{|c|c|c|c|c|c|c|c|}
\hline Parameter & Change & New value & & $\begin{array}{l}\text { Total } \\
\text { cost }(T L)\end{array}$ & YLL & $\begin{array}{l}\text { Cost } \\
\text { difference (TL) }\end{array}$ & $\begin{array}{l}\text { Year } \\
\text { difference }\end{array}$ \\
\hline & & & 3TC-TDF & 132,118 & 3.190 & 12,580 & 1.141 \\
\hline & & & $\mathrm{LdT}$ & 151,059 & 4.099 & 31,521 & 2.050 \\
\hline & & & $3 \mathrm{TC}$ & 147,245 & 6.515 & 27,707 & 4.467 \\
\hline & & & TDF & 119,671 & 2.072 & & \\
\hline & & & ETV-TDF & 161,642 & 2.131 & 41,971 & 0.059 \\
\hline & & & ETV & 162,115 & 2.131 & 42,444 & 0.060 \\
\hline \multirow{7}{*}{$\begin{array}{l}\text { TDF: Virologic response 48th week } \\
\text { in } \mathrm{HBeAg}(+)\end{array}$} & $25 \%$ decrease & $57.1 \%$ & LdT-TDF & 138,211 & 3.056 & 18,540 & 0.985 \\
\hline & & & 3TC-TDF & 132,195 & 3.204 & 12,524 & 1.133 \\
\hline & & & LdT & 151,059 & 4.099 & 31,388 & 2.027 \\
\hline & & & $3 \mathrm{TC}$ & 147,245 & 6.515 & 27,574 & 4.444 \\
\hline & & & TDF & 140,826 & 2.060 & & \\
\hline & & & ETV-TDF & 161,879 & 2.131 & 1053 & 0.070 \\
\hline & & & ETV & 162,115 & 2.131 & 1289 & 0.071 \\
\hline \multirow[t]{7}{*}{ TDF annual drug cost } & $25 \%$ decrease & $2796 \mathrm{TL}$ & LdT-TDF & 144,943 & 3.050 & 4117 & 0.990 \\
\hline & & & 3TC-TDF & 147,174 & 3.197 & 6348 & 1.137 \\
\hline & & & $\mathrm{LdT}$ & 151,059 & 4.099 & 0233 & 2.038 \\
\hline & & & $3 \mathrm{TC}$ & 147,245 & 6.515 & 6419 & 4.455 \\
\hline & & & TDF & 98,383 & 2.060 & & \\
\hline & & & ETV-TDF & 161,405 & 2.131 & 63,022 & 0.070 \\
\hline & & & ETV & 162,115 & 2.131 & 63,732 & 0.071 \\
\hline \multirow[t]{4}{*}{ TDF annual drug cost } & $25 \%$ decrease & $1677 \mathrm{TL}$ & LdT-TDF & 131,421 & 3.050 & 33,038 & 0.990 \\
\hline & & & 3TC-TDF & 117,139 & 3.197 & 18,756 & 1.137 \\
\hline & & & LdT & 151,059 & 4.099 & 52,676 & 2.038 \\
\hline & & & $3 T C$ & 147,245 & 6.515 & 48,862 & 4.455 \\
\hline
\end{tabular}

Tenofovir dominates all comparisons in all scenarios

In the study conducted in Taiwan and published by Veenstra et al. [29], a life-long Markov model was used, and Entecavir monotherapy was found to be more costeffective compared to Lamivudine and Adefovir disoproxil combination treatments. In this analysis, Tenofovir monotherapy was found to be the most cost-effective treatment during the first 5 years, the first 10 years, for 30 years, and for 40 -year life spans, which is similar to the results of the life span assessment.

In a disease burden study about HBV conducted in Vietnam and published in 2008, the average annual HBV disease cost was determined as $\$ 450.35$ for this country [30]. In research conducted in China and published in 2013, the cost of CHB was found to be $\$ 4.136$ [31]. In another study conducted in the US, the average life span cost per capita of HBV was estimated as $\$ 2.667$ [32]. In a cost analysis of immigrants using the 2006 data in Canada, the treatment costs of Entecavir, Tenofovir, Lamivudine, and pegylated interferon (48 weeks) were determined as $\$ 6.504, \$ 5.032, \$ 1.516$, and $\$ 10.185$, respectively [33].
In a hospital-based $\mathrm{CHB}$ and $\mathrm{CHC}$ treatment cost study evaluating 284 patients in the Denizli province in Turkey, it was found that the treatment cost and total cost were higher with the Entecavir treatment compared to the Tenofovir and Lamivudine treatments. PEG Int-2a and $2 \mathrm{~b}$ treatments had a higher cost than Lamivudine, Entecavir, Tenofovir treatments, and no treatment [34].

In an analysis including the US, Germany, and some Asian countries conducted by Lui et al. [35], the most cost-effective treatment was found to be Entecavir and Tenofovir monotherapies among switching from Telbivudine and Lamivudine monotherapies to Tenofovir and Entecavir treatments.

In other studies, Tenofovir was reported to be the most cost-effective treatment among Tenofovir, Entecavir, Telbivudine, and Adefovir treatments [35, 36].

There are limitations of this study as assumptions. All assumptions and articles that were used in the study were taken from three experts' opinions.

In the model presented in this study used for the costeffectiveness analysis of CHB treatments, Tenofovir was 
found to be one of the cost-effective methods in comparison with other treatment strategies at different time intervals. In addition to this achievement, Tenofovir has been shown to reduce the cumulative treatment cost in the first line of $\mathrm{CHB}$ treatment when compared to a 40 -year cumulative treatment cost.

In addition, the sensitivity analysis showed that the most effective parameter is the virologic respond; however, TDF had the lowest cost and the highest effectiveness rates as a cost-effective option in all scenarios.

In conclusion, it could be stated that Tenofovir provides cost-effective results regarding public costs and sustainable health financing by being included in the reimbursement for the first line of CHB treatment both in less years of life lost and the reduced cumulative treatment cost.

\begin{abstract}
Abbreviations
CHB: chronic hepatitis B; HBV: hepatitis B virus; SUT: Healthcare Implementation Notification; YPLL: Years of Potential Life Lost; ICER: incremental costeffectiveness ratio; HBsAg: hepatitis B surface antigen; $\mathrm{Cl}$ : confidence interval; 3TC: lamivudine; LdT: telbivudine; ETV: Entecavir; TDF: Tenofovir; ETV-TDF: switching to tenofovir from entecavir; LdT-TDF: switching to tenofovir from telbivudine; 3TC-TDF: switching to tenofovir from lamivudine; SSI: Social Security Institution; YLL: years of life lost.
\end{abstract}

\section{Authors' contributions}

GK helped to design the health economics model and prepare the article. AK helped to review the literature and prepare the article. FBY helped to review the literature and prepare the article. $\mathrm{OO}$ helped to design the health economics model. EK helped to review the literature. All authors read and approved the final manuscript.

\section{Author details \\ ${ }^{1}$ Gilead Sciences Turkey, Istanbul, Turkey. ${ }^{2}$ Akıl Consultancy, Ankara, Turkey. ${ }^{3}$ Yorum Consultancy, Istanbul, Turkey.}

\section{Competing interests}

The analysis was conducted under Gilead Sciences Turkey's unconditional sponsorship. Guvenc Kockaya, Akın Kose and Ece Kucuksayrac are the employee of Gilead Science Turkey. Oktay Ozdemir is the health economics and modeling consultant of Gilead Science Turkey. Fatma Betul Yenilmez is contractor consultant of Gilead Science Turkey.

Received: 13 March 2015 Accepted: 18 November 2015

Published online: 10 December 2015

\section{References}

1. Lavanchy D. Hepatitis B virus epidemiology, disease burden, treatment, and current and emerging prevention and control measures. JViral Hepatitis. 2004;11(2):97-107.

2. Mahoney FJ. Update on diagnosis, management, and prevention of hepatitis B virus infection. Clin Microbiol Rev. 1999;12(2):351-66.

3. Toy M. Age and region-specific hepatitis B prevalence in Turkey estimated using generalized linear mixed models: a systematic review. BMC Infect Dis. 2011;11:337.

4. EASL Clinical Practice Guidelines. J Hepatol. 2012;57:167-85.

5. Lok ASF, McMahon BJ. Chronic hepatitis B: update 2009. Hepatology. 2009;50:1-36.

6. Liaw YF, Kao JH, Piratvisuth T, Chan HLY, Chien RN, Liu CJ, Gane E, Locarnini S, Lim SG, Han KH, Amarapurkar D, Cooksley G, Jafri W, Mohamed R, Hou JL, Chuang WL, Lesmana LA, Sollano J, Suh DJ, Omata M. Asian-Pacific consensus statement on the management of chronic hepatitis B: a 2012 update. Hepatol Int. 2012;6:531-61.
7. Liaw YF, Gane E, Leung N, Zeuzem S, Wang Y, Lai CL, et al. 2-Year GLOBE trial results: telbivudine Is superior to lamivudine in patients with chronic hepatitis B. Gastroenterology. 2009;136:486-95.

8. Turkish Statistics Agency, Population Statics 2014. http://www.tuik.gov.tr/ UstMenu.do?metod=temelist. Last updated 29.09.2015.

9. Yamazhan T, Kurtaran B, Pullukcu H, Yuksel E, Ozkaya D, Tasbakan MI, Sipahi OR, Durusoy R, Aksu HSZ. Pegylated interferon in HBeAg-positive and -negative chronic hepatitis B patients: posttreatment 1-year results of three Turkish centres. J Chemother. 2014;26(6):339.

10. Health Application Notification (SUT). Link http://mevzuat.basbakanlik. gov.tr/Metin.Aspx?MevzuatKod=9.5.17229\&Mevzuatlliski=0\&sourceXmlS earch=saC49FIC4B1 k20. (Last: Updated: 16.10.2014).

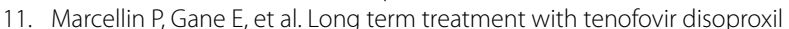
fumarate for chronic hepatitis $b$ infection is safe and well tolerated and associated with durable virologic response with no detectable resistance: 8 year results from two phase 3 trials [AASLD abstract 229]. Hepatology. 2014:60(4):313A.

12. Marcellin $P$, Gane E, Buti M, et al. Regression of cirrhosis during treatment with Tenofovir disoproxil fumarate for chronic hepatitis B: a 5-year openlabel follow-up study. Lancet. 2013;381:468-75.

13. Kanwal F, Gralnek IA, Martin P, Dulai GS, Farid M, Spiegel BMR. Treatment alternatives for chronic hepatitis $B$ virus infection: a cost-effectiveness analysis. Ann Intern Med. 2005;142:821-31.

14. Tenney DJ, Rose RE, Baldick CJ, Pokornowski KA, Eggers BJ, Fang J, Wichroski MJ, Xu D, Yang J, Wilber RB, Colonno RJ. Long-term monitoring shows hepatitis B virus resistance to Entecavir in nucleoside-naiive patients is rare through 5 years of therapy. Hepatology. 2009:49(5):1503-14.

15. Chae HB, Hann HW. Baseline HBV DNA level is the most important factor associated with virologic breakthrough in chronic hepatitis B treated with Lamivudine. World J Gastroenterol. 2007;13(30):4085-90.

16. Zeuzem S, Gane E, Liaw YF, Lim SG, DiBisceglie A, Buti M, Chutaputti A, Rasenack J, Hou J, O'Brien C, Nguyen TT, Jia J, Poynard T, Belanger B, Bao W, Naoumov NV. Baseline characteristics and early on-treatment response predict the outcomes of 2 years of Telbivudinee treatment of chronic hepatitis B. 2009;51(1):11-20.

17. Marcellin P, Heathcote EJ, Buti M, Gane E, Man RA, Krastev Z, Germanidis G, Lee SS, Flisiak R, Kaita K, Manns M, Iskren Kotzev I, Tchernev K, Buggisch P, Weilert F, Kurdas OO, Shiffman ML, Trinh H, Washington MK, Sorbel J, Anderson J, Snow-Lampart A, Mondou E, Quinn J, Rousseau F. Tenofovir disoproxil fumarate versus adefovir dipivoxil for chronic hepatitis B. N Engl J Med 2008;359:2442-55.

18. Arnold E, Yuan Y, lloeje U, Cook G. Cost-effectiveness analysis of entecavir versus lamivudine in the first-line treatment of Australian patients with chronic hepatitis B. Appl Health Econ Health Policy. 2008;6(4):231-46.

19. Yuan Y, lloeje UH, Hay J, ve Saab S. Evaluation of the Cost-Effectiveness of Entecavir Versus Lamivudine in Hepatitis BeAg-Positive Chronic Hepatitis B Patients. J Manag Care Pharm. 2008;14(1):21-33.

20. Lai CL, Gane E, Liaw YF, Hsu CW, Thongsawat S, Wang Y, Chen Y, Heathcote EJ, Rasenack J, Bzowej N, Naoumov NV, Di Bisceglie AM, Zeuzem S, Moon YM, Goodman Z, Chao G, Constance BF, Brown NA, Globe Study Group. Telbivudine versus lamivudine in patients with chronic hepatitis B. N Engl J Med. 2007:357(25):2576-88.

21. Tatar M, ve Al. SağıkTeknolojilerinin Değerlendirilmesi_-llaç Geri Ödeme Kararları İçin Bir Model Önerisi. Ankara: MN Medikal \& Nobel Basım Yayın; 2010.

22. Malhan S, Oksuz E, Eminsoy G, Sözen F, Ünsal A, Ersoy K."Kronik Hepatit B ve Komplikasyonlarının Geri Ödeme Kurumu Perspektifinden Türkiye'ye Maliyeti"The Turkish J Gastroentrology 2009; 20(1):207.

23. Iloeje UH, Yang HI, Su J, Jen CL, You SL, Chen CJ, Risk Evaluation of Viral Load Elevation and Associated Liver Disease/Cancer-In HBV (the REVEALHBV) Study Group. Predicting cirrhosis risk based on the level of circulating hepatitis B viral load. Gastroenterology. 2006;130(3):678-86.

24. Orlewska E, Zammit D, Yuan Y, Kutikova L, Berak H, Halota W, ve Hay JW. The cost effectiveness analysis Entecavir in the treatment chronic hepatitis B (CHB) patients in Poland. Hepatology. 2008:4(3-4):20-8.

25. Chen CJ, Yang HI, Su J, Jen CL, You SL, Lu SN, Huang GT, Iloeje UH, REVEALHBV Study Group. Risk of hepatocellular carcinoma across a biological gradient of serum hepatitis B virus DNA level. JAMA. 2006;295(1):65-73.

26. TUIK Life Expectacy on Birth. Link http://www.tuik.gov.tr/UstMenu. do?metod=temelist. Last Updated 16.08.2014. 
27. Koçkaya G, Wertheimer A, Daylan Kockaya P, Esen A. Considering the cost-effectiveness of statins in family practice in Turkey from a payer perspective. Health. 2009;1:274-80.

28. Hamby DM. A comparison of sensitivity analysis techniques Oregon State University. Link http://web.engr.oregonstate.edu/ hambydm/papers/ senscomparison.pdf. Last updated 21.10.2015.

29. Veenstra DL, Sullivan SD, Lai MY, Lee CM, Tsai CM, Patel KK. HBeAgNegative Chronic Hepatitis B: Cost-Effectiveness of Peginterferon Alfa-2a Compared to Lamivudine in Taiwan. Value Health. 2008;11(2):131-9.

30. Tu AHT, Woerdenbag HJ, Riewpaiboon A, Kane S, Le DM, Postma MJ, L SC. Cost of illness of chronic hepatitis B infection in Vietnam. Value Health Reg Isssues. 2012;1(2012):23-8.

31. Lu J, Xu A, Wang J, Zhang L, Song L, Li R, Zhang S, Zhuang G, Lu M. Direct economic burden of hepatitis $B$ virus related diseases: evidence from Shandong, China. BMC Health Serv Res. 2013;13:37.

32. Owusu-Edusei K Jr, Chesson HW, Gift TL, Tao G, Mahajan R, Ocfemia MC, Kent CK. The estimated direct medical cost of selected sexually transmitted infections in the United States, 2008. Sex Transm Dis. 2013:40(3):197-201. doi:10.1097/OLQ.0b013e318285c6d2

33. Wong WWL, Woo G, Heathcote EJ, Krahn M. Disease burden of chronic hepatitis B among immigrants in Canada. Can J Gastroenterol. 2013;27(3):137-47.

34. Karahasanoğlu FB, Asan A, Sacar S, Turgut H. Costs of treatment, followup, and complications of chronic hepatitis B and hepatitis $C$ infections. Balkan Med J. 2013;30:375-81.

35. Lui YYN, Tsoi KKF, Wong VWS, Kao JH, Hou JL, Teo EK, Mohamed R, Piratvisuth T, Han KH, Mihm U, Wong GLH, Chan HLY. Cost-effectiveness analysis of roadmap models in chronic hepatitis $\mathrm{B}$ using Tenofovir as the rescue therapy. Antiviral Therapy. 2010;15:145-55.

36. Buti M, Brosa M, Casado MA, Rueda M, Esteban R. Modeling the costeffectiveness of different oral antiviral therapies in patients with chronic hepatitis B. J Hepatol. 2009;51:640-6.

\section{Submit your next manuscript to BioMed Central and we will help you at every step:}

- We accept pre-submission inquiries

- Our selector tool helps you to find the most relevant journal

- We provide round the clock customer support

- Convenient online submission

- Thorough peer review

- Inclusion in PubMed and all major indexing services

- Maximum visibility for your research

Submit your manuscript at www.biomedcentral.com/submit

O) Biomed Central 